THE WILLIAM DAVIDSON INSTITUTE

AT THE UNIVERSITY OF MICHIGAN

\title{
INTERNATIONAL FINANCIAL INTEGRATION AND REAL EXCHANGE RATE LONG-RUN DYNAMICS IN EMERGING COUNTRIES: SOME PANEL EVIDENCE
}

By: Guglielmo Maria CAPORALE, Thouraya HADJ AMOR and Christophe RAULT

William Davidson Institute Working Paper Number 970

September 2009 


\title{
INTERNATIONAL FINANCIAL INTEGRATION AND REAL EXCHANGE RATE LONG-RUN DYNAMICS IN EMERGING COUNTRIES: SOME PANEL EVIDENCE
}

\author{
Guglielmo Maria CAPORALE \\ Brunel University (London), CESifo and DIW ${ }^{1}$ \\ Thouraya HADJ AMOR \\ University of Tunis El Manar, URMOFIB, and University of Nice Sophia-Antipolis, \\ CEMAFI $^{2}$ \\ Christophe RAULT \\ LEO, University of Orléans, CESifo, IZA, and William Davidson Institute ${ }^{3}$
}

\begin{abstract}
The aim of this paper is to provide new empirical evidence on the impact of international financial integration on the long-run Real Exchange Rate (RER) in 39 developing countries belonging to three different geographical regions (Latin America, Asia and MENA). It covers the period 1979-2004, and carries out "second-generation" tests for non-stationary panels. Several factors, including international financial integration, are shown to drive the long-run RER in emerging countries. It is found that the new financial environment characterised by international financial integration leads to a depreciation of the RER in the long run. Further, RER misalignments take the form of an under-valuation in most MENA countries and an over-valuation in most Latin American and Asian countries.
\end{abstract}

Keywords: emerging economies, real exchange rate, financial integration, misalignment, secondgeneration panel unit-root and cointegration tests

JEL Classification: E31, F0, F31, C15.

We are very grateful to two anonymous referees for helpful comments and suggestions on an earlier draft of this paper. The usual disclaimer applies.

\footnotetext{
${ }^{1}$ Centre for Empirical Finance, Brunel University, Uxbridge, Middlesex UB8 3PH, UK. Email: Guglielmo-Maria.Caporale@brunel.ac.uk.

${ }^{2}$ University of Nice Sophia-Antipolis, Avenue Dean Louis Trotabas 06050 Nice, France. E-Mail: hathouraya@yahoo.fr.

${ }^{3}$ Université d'Orléans, LEO, CNRS, UMR 6221, Rue de Blois-B.P.6739, 45067 Orléans Cedex 2, France; CESifo and IZA, Germany; and William Davidson Institute at the University of Michigan, Ann Arbor, Michigan, USA; email: chrault@hotmail.com. Web-site: http://chrault3.free.fr/ (corresponding author).
} 


\section{Non-Technical Summary}

The post-Bretton Woods period has been characterised not only by freely floating currencies but also by international financial liberalisation (see Eatwell, 1996), more specifically the abolition of capital controls and the deregulation of domestic financial markets (see Mussa and Goldstein, 1993), with a consequent reduction in the barriers to foreign direct investment and trade (see Obstfeld, 1998, Baldwin and Martin 1999). However, there were also unintended consequences in terms of greater instability (see Blecker, 2005), trade disequilibria, financial crises, high volatility of the exchange rate and persistent deviations from PPP (see Frankel and Rose 1996, Reinhart and Smith 2001, Stiglitz 2002, Krugman and Obstfeld 2003). Therefore, there has been renewed interest in the long-run determinants of real exchange rates in order to assess possible misalignments.

The evaluation of misalignment requires prior determination of a reference or equilibrium RER, in the absence of which the concepts of under- or over-evaluation of a currency relative to another have little meaning (see Edwards and Savastano, 1999). This is often based on PPP (despite the mixed evidence on whether this holds in practice and the so-called PPP "puzzle" - see Rogoff 1996), or alternatively on the fundamental Equilibrium Real Exchange Rate (RER) concept developed by Williamson (1985, 1994), Stein (1994, 1995) and MacDonald (1999). Such work has focused primarily on the industrial economies. Only a few papers have analysed the case of developing countries and emerging countries (see Edwards 1987, 1988, 1989, Elbadawi 1994, and Neary 1988). Whilst the theoretical and empirical literature mainly agrees on the adverse impact of financial integration on RER volatility in most emerging countries (see Obstfeld 1984, Ferrari 2000, Reinhart and Smith 2001, Stiglitz 2001, Eatwell and Taylor 2002, Corden 2002, Prasad and al. 2003), very limited research has been done on its effects on the long-run RER and possible misalignments, with mixed results. Some authors argue that international financial integration increases RER misalignments, because it is accompanied by a floating exchange rate regime (Ferrari, 2000). Others instead hold the view that it leads to a period of RER undervaluation (Hooper and Morton, 1982, Gavin, 1992), which can promote economic growth in emerging countries.

The aim of this paper is to shed light on the determinants of the long-run equilibrium RER in emerging countries and to assess possible misalignments, focusing in particular on the long-run effects of international financial integration. Its contribution to the literature is twofold. First, we include international financial integration in the standard reduced-form model of the RER to test its impact on the long-run equilibrium and whether it leads to misalignments. Second, we carry out "secondgeneration" unit root and cointegration panel tests (taking into account possible cross-sectional dependence), which had not been previously done in this context. Using this approach, we are able to confirm the existence of a long-run relationship between the RER and various factors (including 
international financial integration) for all four panels considered (all countries, Latin America, Asia, the MENA), in contrast to what is concluded when relying on asymptotic critical values (which are not reliable for statistical inference here).

Our econometric analysis indicates that several factors affect the long-run RER, the signs of the estimated coefficients being consistent with theory. It is found that, in addition to other determinants normally considered in exchange rate models, international financial integration plays a key role, and has resulted in long-run RER depreciation and undervaluation. Also, persistent and recurrent misalignments are common in emerging economies, and take the form of an under-valuation in most MENA countries and an overvaluation in most Latin American and Asian countries. The latter two groups of countries would find it beneficial to adopt a more flexible exchange rate system (more compatible with the new financial architecture) in order to reduce RER misalignments. 


\section{Introduction}

The post-Bretton Woods period has been characterised not only by freely floating currencies but also by international financial liberalisation (see Eatwell, 1996), more specifically the abolition of capital controls and the deregulation of domestic financial markets (see Mussa and Goldstein, 1993), with a consequent reduction in the barriers to foreign direct investment and trade (see Obstfeld, 1998, Baldwin and Martin 1999). However, there were also unintended consequences in terms of greater instability (see Blecker, 2005), trade disequilibria, financial crises, high volatility of the exchange rate and persistent deviations from PPP (see Frankel and Rose 1996, Reinhart and Smith 2001, Stiglitz 2002, Krugman and Obstfeld 2003). Therefore, there has been renewed interest in the long-run determinants of real exchange rates in order to assess possible misalignments.

The evaluation of misalignment requires prior determination of a reference or equilibrium RER, in the absence of which the concepts of under- or over-evaluation of a currency relative to another have little meaning (see Edwards and Savastano, 1999). This is often based on PPP (despite the mixed evidence on whether this holds in practice and the so-called PPP "puzzle" - see Rogoff 1996), or alternatively on the fundamental Equilibrium Real Exchange Rate (RER) concept developed by Williamson (1985, 1994), Stein (1994, 1995) and MacDonald (1999). Such work has focused primarily on the industrial economies. Only a few papers have analysed the case of developing countries and emerging countries (see Edwards 1987, 1988, 1989, Elbadawi 1994, and Neary 1988). Whilst the theoretical and empirical literature mainly agrees on the adverse impact of financial integration on RER volatility in most emerging countries (see Obstfeld 1984, Ferrari 2000, Reinhart and Smith 2001, Stiglitz 2001, Eatwell and Taylor 2002, Corden 2002, Prasad and al. 2003), very limited research has been done on its effects on the long-run RER and possible misalignments, with mixed results. Some authors argue that international financial integration increases RER misalignments, because it is accompanied by a floating exchange rate regime (Ferrari, 2000). Others instead hold the view that it leads to a period of RER undervaluation (Hooper and Morton, 1982, Gavin, 1992), which can promote economic growth in emerging countries.

The aim of this paper is to provide new empirical evidence on the impact of international financial integration on the long-run RER in 39 developing countries belonging to three different geographical regions (Latin America, Asia and MENA). It covers the period 1979-2004, and carries out "secondgeneration" tests for non-stationary panels. The layout of the paper is as follows. Section 2 provides an overview of the literature on the effects of financial integration on the RER in emerging countries. Section 3 presents some empirical evidence based on the estimation of a reduced-form model exploiting recent developments in the econometrics of dynamic non-stationary panels which take into account cross-sectional dependence. Specifically, we use the bootstrap panel unit root test of Smith et 
al. (2004), and the bootstrap cointegration test of Westerlund and Edgerton (2007). To our knowledge, ours is the first application of such tests in this context. Finally, Section 4 summarises the main findings and offers some concluding remarks.

\section{Literature Review}

\subsection{Theory}

Over the years a number of theoretical studies have examined the effects of financial integration on the real exchange rate. Bruno (1976) shows that the impact of liberalisation depends on the domestic interest rate prevailing beforehand and the depreciation of the adjusted foreign exchange rate. When the former exceeds the latter, following the abolition of capital controls the RER begins to appreciate if there is excess domestic demand and a current account deficit. Consequently, there is an initial period of real appreciation, but a real depreciation in the long run: the initial shock decreases the stock of foreign assets held in the country, and therefore long-run depreciation occurs (assuming that the domestic capital stock remains constant). Calvo (1982) and Khan and Zahler (1983) also examine the effects on the capital account and on the stock of wealth.

Obstfeld (1984) presents a model where there is an initial period of real appreciation and a real depreciation in the long run because of the removal of capital controls. Also, there is a demand shift towards domestic goods, and a higher RER leads to an increase in imports of intermediate products. Consistently with the Marshall-Lerner condition, a RER depreciation (appreciation) is associated with a current account surplus (deficit). Dornbusch and Fischer (1980), Hooper and Morton (1982), and Gavin (1992) examine the relationship between Net Foreign Assets (NFA) and RER 4 . Hooper and Morton (1982) develop a model in which exogenous shocks to trade result, in the long run, in a positive correlation between NFA and RER. In a more complete theoretical model, Gavin (1992) shows that exogenous shocks to wealth entail a positive correlation between NFA and RER, if the Marshall- Lerner condition is satisfied. The idea is that in equilibrium a country having a negative NFA must have a trade surplus to finance interest and dividend payments on these foreign assets ${ }^{5}$. The mechanism used to produce this surplus is a RER depreciation. Any NFA shock may affect the longrun RER. More recently, Alberola (2003) has pointed out that “... the equilibrium relative price in the tradable sector is defined as the one that allows the current account to reach a level that is consistent with desired capital outflows or inflows, the latter being proportional to the discrepancy between the desired and observed levels of the net foreign asset (NFA) position"6. There is an obvious interaction

\footnotetext{
${ }^{4}$ Net foreign assets (NFA) represent wealth and affect domestic demand through intertemporal optimisation. Higher demand for goods leads to lower relative prices of non-tradable goods, and an appreciating RER.

${ }^{5}$ According to Marquez (1990), elasticities comply with this condition, at least in the long run (see also Morel and Perron 2003).

${ }^{6}$ Benassy-Quéré, Duran-Vigneron, Lahrèche-Révil and Mignon (2004, p 10).
} 
between capital and trade accounts, which provides another link between the country's position in terms of net foreign assets and the exchange rate: a debtor country may require a real depreciation in the long run to generate trade surpluses (Milesi-Ferretti, 2005).

Lane and Milesi-Feretti (2001) set up a new open macroeconomics model of inter-temporal optimisation where the prices of non-tradable goods are endogenous. They link RER and debt through variables such as the terms of trade and productivity (the Balassa-Samuelson effect). They conclude that creditor (developed) countries have an appreciating RER while debtor (developing) countries have a depreciating RER. Ganelli et al., (2002) and Breton (2004) develop overlapping generations models a la Blanchard et al. (1989). Egert et al., (2004) and Benassy-Quéré et al (2004) show that in the long run NFA reaches its desired level. A higher NFA leads to a RER appreciation because of higher capital inflows. Countries with a negative NFA stock (transition economies) register a current account deficit and a real appreciation. However, the medium term is characterised by the adjustment of net external assets to their desired level, and, in the long run, the desirable NFA level can be achieved.

To sum up, the theoretical literature provides a variety of models highlighting different factors (such as the level of the interest rate, capital controls, the NFA position etc.) which might determine how international financial integration will affect the equilibrium RER, and make different theoretical predictions about such effects.

\subsection{Empirical studies}

The empirical literature provides mixed results. The model of Obstfeld (1984) suggests that the abolition of capital controls leads to a short-run real appreciation of RER, an external deficit and higher capital inflows (as in the Latin American countries where economic reforms were implemented). In the long run, liberalisation entails instead a RER depreciation. He found that the stability of the system implies that the stock of external long-term will decline. However, in Chile, the real appreciation started prior to the removal of external financial restrictions (see Edwards, 1989a). Hopper and Morton (1982), Faruquee (1995), Obstfeld and Rogoff (1995) and Gagnon (1993) also find a positive correlation between NFA and RER. Burgess et al (2003) report the same for three Baltic States, and Alonso-Gamo et al. (2002) and Lammatzsh and Tober (2002) for Lithuania, the Czech Republic, Hungary and Poland. On the other hand, Hinnosar et al., (2003) report a negative relationship in the case of Estonia, and so does Rahn (2003) for the Czech Republic, Estonia, Hungary, Poland and Slovenia. Alberola (2003), Csajbok (2003), Darvas (2001), and Bitans and Tillers (2003) reach the same conclusion for Hungary and Poland. Bénassy-Quéré et al. (2004) analyse the long-run effects of NFA on the RER for the G-20 countries for the period 1980 - 2002. Using a "firstgeneration" panel cointegration approach, they find that a decrese in NFA in emerging economies 
caused a real RER appreciation in the second half of the period ${ }^{7}$. Égert, Lahrèche-Révil and Lommatzsch (2004) using the same technique showed that an improvement in the NFA position leads to a real appreciation in the small open economies of the OECD. In contrast, in the case of transition economies the deterioration in the NFA is consistently associated with a real appreciation. They suggest that the difference in the sign of the estimated coefficient may be due to the fact that the thirtyyear period used for the OECD countries captures the long run, while the decade of data available for the transition countries can only be informative about the medium run.

Lane and Milesi-Ferretti (2005) examine the interactions between financial globalisation and RER. They use assets and the external commitments of a sample of emerging economies to estimate the deterioration of the net foreign asset position during periods of debt crisis. They provide evidence of a stabilisation of the NFA position in the period 1990-1996, followed by a deterioration caused by the decline of GDP and the RER depreciation at the time of the Asian crisis, and a subsequent improvement in the combined current account surplus for Asia. Elbadawi and Kamar (2005) introduce in their model other financial variables such as financial development, and consider the MENA region, finding a long- run relationship between RER and fundamentals.

Although the literature on the effect of financial liberalisation on long-run real exchange rates is vast, very few studies have focused on emerging economies. Some recent ones have analysed the structural determinants of exchange rates in order to identify and evaluate misalignments, but none have focused on IFI as a factor directly affecting the long-run equilibrium RER in emerging countries, which instead we do in the following analysis.

\section{Econometric analysis for a panel of 39 emerging countries}

In this Section we examine the effects of financial integration on the long-run RER by estimating reduced-form equations linking the real exchange rate to various factors including international financial integration. Our analysis covers a sample of 39 emerging countries divided into three groups: 9 MENA countries (Algeria, Egypt, Iran, Israel, Jordan, Morocco, Syria, Tunisia, Turkey), 10 Asian

\footnotetext{
${ }^{7}$ Our approach differs from that of Bénassy-Quéré et al. (2004) for at least three reasons. Firstly, we deal with 39 developing countries belonging to three different geographical regions (Latin America, Asia and MENA), rather than developed ones (G20). Secondly, our purpose is different since we investigate the long-term behaviour of the RER from the point of view of the new financial architecture, and extend existing studies by considering the possible effect of international financial integration on the RER long-run dynamics. By contrast, Bénassy-Quéré et al. (2004) examine the effect of net foreign asset on the equilibrium RER. Thirdly, BénassyQuéré et al. (2004) use first-generation panel unit root and cointegration tests developed on the assumption of cross-sectional independence of panel units, an assumption that is unrealistic in many empirical settings. Our analysis performs instead second-generation tests allowing for various types of dependence across the different units.
} 
countries (Bangladesh, China, India, Indonesia, Korea, Malaysia, Pakistan, Philippines, Sri Lanka, Thailand), and 20 Latin American countries (Argentina, Bolivia, Brazil, Chile, Colombia, Costa Rica, Dominican Republic, Ecuador, El Salvador, Guatemala, Haiti, Honduras, Mexico, Nicaragua, Panama, Paraguay, Peru, Trinidad, Uruguay, Venezuela). The sample period is from 1979 to 2004 and the frequency of the data is annual. Having tested for the existence of a long-run relationship between RER and its determinants, we then measure the differences as RER misalignments.

\subsection{Reduced -form model}

We add international financial integration to the standard equation for long-run RER (see Edwards, 1993; MacDonald, 1998; Drine and Rault, 2005), which is therefore specified as follows (in logs):

$$
\begin{array}{r}
\operatorname{Rer}_{\text {it }}=\beta_{0}+\beta_{1} \mathrm{tt}_{\mathrm{it}}+\beta_{2} \mathrm{dprod}_{\mathrm{it}}+\beta_{3} \mathrm{ps}_{\mathrm{it}}+\beta_{4} \mathrm{mon}_{\text {it }}+\beta_{5} \mathrm{Open}_{\text {it }}+\beta_{6} \mathrm{ifi}_{\mathrm{it}}+\varepsilon_{\text {it }} \\
\mathrm{i}=1 \ldots \mathrm{N} \text { et } \mathrm{t}=1 \ldots \mathrm{T}
\end{array}
$$

where RER stands for the real effective exchange rate defined such that a RER increase (decrease) represents an appreciation (depreciation); tt, the terms of trade; dprod, the productivity differential; ps, the share of public expenditure in GDP, mon, the money stock; open, trade openness; ifi, international financial integration; and $\boldsymbol{\varepsilon}_{\mathrm{it}}$, the disturbance term. The data are taken from the IMF's International Financial Statistics (IFS, 2006), World Development Indicators (WDI, 2006) and Calderon (2006), except for the variable measuring international financial integration, which is from Lane and MilesiFerretti $(2006)^{8}$. Three indicators are considered: stocks of FDI and portfolio investment related to GDP (IFI1), total liabilities and assets relative to GDP (IFI2) and NFA position. We use IFI2 for the panel including all countries and for Latin America, and NFA for Asia and MENA ${ }^{9}$. Note that, as public expenditure cannot be broken down into expenditure on tradable and non-tradable goods, we use the share of total expenditure in income as a proxy. Also, no direct measures of labour productivity in the two sectors can be constructed, and therefore GDP per capita growth differential is used as an indicator of technical progress. Finally, the share of imports and exports in total household expenditure is used as a measure of trade openness.

\footnotetext{
${ }^{8}$ For further details on these three alternative measures of international financial integration we refer the reader to the papers by Milesi Ferretti et al. (2005 and 2006) (from which these three measures were taken), that examines trends in gross and net international investment positions and their components for a large set of advanced and developing economies and that includes in an appendix graphs and statistics about these measures of international financial integration.

${ }^{9}$ Note that for each of the different groups of countries (all emerging countries, Latin America, Asia, MENA) we have retained the measure of IFI that was the most statistically significant.
} 


\subsection{Econometric Results}

\subsection{1 "Second-generation" panel unit root tests}

The literature on panel unit root and panel cointegration testing has developed considerably in the past few years and now distinguishes between "first-generation" tests [Maddala and Wu (1999), Levin et al. (2002) and Im et al. (2003)] based on the assumption of the cross-sectional independence between panel units (except for common time effects), and "second-generation tests" [Bai and $\mathrm{Ng}$ (2004), Smith et al.(2004), Moon and Perron (2004), Choi (2006) and Pesaran (2007)] allowing for crosssectional dependence, and also panel data unit root tests allowing for structural breaks [Im and Lee (2001)]. In our analysis, we apply the most recent tests.

As a first step, in order to determine the degree of integration of the series (real exchange rate, terms of trade, productivity differentials, government spending, money, trade openness, financial integration, net foreigner position) in our four panels (all countries simultaneously, Latin America, Asia, MENA), we employ the bootstrap tests of Smith et al. (2004), which use a "Sieve" bootstrap method, taking into account both the sample size and possible dependence between countries of the panel, generating appropriate empirical critical values ${ }^{10}$. The specific tests that we consider are denoted $\bar{t}, \overline{L M}, \overline{\max }$, and $\overline{\min }$, where $\bar{t}$ is the bootstrap version of the well-known panel unit root test of Im et al. (2003), $\overline{L M}=N \sum_{i=1}^{-1} L M_{i}$ is a mean of the individual Lagrange Multiplier $\left(\mathrm{LM}_{\mathrm{i}}\right)$ test statistics, originally introduced by Solo (1984), $\max$ is the test of Leybourne (1995), and $\overline{\min }=N \sum_{i=1}^{-1} \min _{i}$ is a (more powerful) variant of the individual Lagrange Multiplier $\left(\mathrm{LM}_{\mathrm{i}}\right)$, with $\min _{i}=\min \left(L M_{f i}, L M_{r i}\right)$, where $L M_{f i}$ and $L M_{r i}$ are based on forward and backward regressions (see Smith et al., 2004 for further details). We used bootstrap blocks of $\mathrm{m}=20^{11}$.

The null hypothesis for each of them is that of a unit root for the panel of countries, the alternative that of heterogeneous autoregressive roots less than unity for each country. Thus, rejection of the null

\footnotetext{
${ }^{10}$ It should be noted that, before carrying out the second-generation panel unit-root tests that allow for crosssection dependence, we have implemented the simple test of Pesaran (2004) and have computed the CD statistic to test for the presence of such cross-section dependence in the data. This test is based on the average of pairwise correlation coefficients of the OLS residuals obtained from standard augmented Dickey-Fuller regressions for each individual unit. Its null hypothesis is cross-sectional independence and it follows asymptotically a twotailed standard normal distribution. The null hypothesis is always rejected for all series for all emerging countries, as well for each of the three groups of countries, regardless of the number of lags included in the augmented DF auxiliary regression (up to five lags) at the five and ten percent level of significance. This confirms that the members of our panel are cross-sectionally correlated and that therefore any first generation panel unit root tests (which assume cross-country independence), such as the test by Hadri (2000), would be flawed and cannot be used here.

${ }^{11}$ The results are not very sensitive to the size of the bootstrap blocks.
} 
indicates that at least one country in the panel does not have a unit root and is stationary ${ }^{12}$. The results in Table 1 suggest that in most cases the null hypothesis of a unit root cannot be rejected at the usual significance levels for the real exchange rate, terms of trade, productivity differential, government spending, money, trade openness, financial integration and net external position ${ }^{13}$. In addition, tests conducted on the series in first differences (not reported here but available on request) confirm the hypothesis of stationarity. We can therefore conclude that all series are integrated of order one.

\footnotetext{
${ }^{12}$ The lag order in the individual ADF type regressions is selected for each series using the AIC model selection criterion.

${ }^{13}$ Note that to deal with the few borderline cases reported in Table 1 where the joint non-stationary null is (marginally) rejected at the 10\% (though not at the 5\%) level (for example, MENA countries/public spending), we have investigated the robustness of the results by implementing the recent CIPS panel unit root test developed by Pesaran (2007), who showed that, by augmenting the usual ADF regression with the first difference and the first lag of the cross-sectional mean, one can account for the cross-sectional dependence arising through a single stationary factor. The results of this other second-generation panel unit root tests (available upon request) provide clear support for the existence of a unit root in all series under consideration at the five and ten percent level of significance.
} 
Table 1 - Panel tests of Smith and al. (2004) for real exchange rates, terms of trade, productivity differentials, government spending, money, trade openness, financial integration and net external position

\begin{tabular}{|c|c|c|c|c|c|c|c|c|c|c|c|c|c|c|c|c|}
\hline & \multicolumn{2}{|c|}{ Real Exchange Rate } & \multicolumn{2}{|c|}{ Term of Trade } & \multicolumn{2}{|c|}{$\begin{array}{l}\text { Productivity } \\
\text { Differential }\end{array}$} & \multicolumn{2}{|c|}{ Public spending } & \multicolumn{2}{|c|}{ Money } & \multicolumn{2}{|c|}{ Trade Openness } & \multicolumn{2}{|c|}{$\begin{array}{c}\text { Financial } \\
\text { Integration }\end{array}$} & \multicolumn{2}{|c|}{ Net Foreign Assets } \\
\hline Test & Statistic & $\begin{array}{l}\text { Bootstrap } \\
\text { P-value* }\end{array}$ & Statistic & $\begin{array}{l}\text { Bootstrap } \\
\text { P-value* }\end{array}$ & Statistic & $\begin{array}{l}\text { Bootstrap } \\
\text { P-value* }\end{array}$ & Statistic & $\begin{array}{l}\text { Bootstrap } \\
\text { P-value* }\end{array}$ & Statistic & $\begin{array}{l}\text { Bootstrap } \\
\text { P-value* }\end{array}$ & Statistic & $\begin{array}{l}\text { Bootstrap } \\
\text { P-value* }\end{array}$ & Statistic & $\begin{array}{l}\text { Bootstrap } \\
\text { P-value* }\end{array}$ & Statistic & $\begin{array}{l}\text { Bootstrap } \\
\text { P-value* }\end{array}$ \\
\hline \multicolumn{17}{|c|}{ All countries considered together (1979-2004) } \\
\hline$t$ & -2.230 & 0.154 & -1.647 & 0.342 & -1.235 & 0.172 & -2.647 & 0.155 & -1.893 & 0.193 & -1.258 & 0.258 & -1.548 & 0.381 & -1.258 & 0.321 \\
\hline$\overline{L M}$ & 5.624 & 0.060 & 3.524 & 0.125 & 4.125 & 0.084 & 5.557 & 0.060 & 3.621 & 0.121 & 2.258 & 0.394 & 4.256 & 0.075 & 3.129 & 0.157 \\
\hline $\max$ & -1.981 & 0.207 & -1.677 & 0.211 & -1.281 & 0.271 & -1.977 & 0.208 & -1.745 & 0.271 & -0.587 & 0.621 & -0.987 & 0.287 & -1.287 & 0.281 \\
\hline$\overline{\min }$ & 3.642 & 0.292 & 2.764 & 0.421 & 2.414 & 0.510 & 3.768 & 0.282 & 1.968 & 0.198 & 3.478 & 0.314 & 2.289 & 0.192 & 2.859 & 0.365 \\
\hline \multicolumn{17}{|c|}{ Latin America (1979-2004) } \\
\hline$t$ & -3.258 & 0.258 & -1.258 & 0.428 & -1.589 & 0.189 & -3.125 & 0.128 & -1.991 & 0.258 & -1.625 & 0.194 & -1.471 & 0.274 & -1.365 & 0.274 \\
\hline$\overline{L M}$ & 2.236 & 0.268 & 2.237 & 0.178 & 3.148 & 0.125 & 5.851 & 0.051 & 4.251 & 0.254 & 2.365 & 0.368 & 3.358 & 0.145 & 3.123 & 0.162 \\
\hline $\max$ & -1.258 & 0.125 & -2.258 & 0.145 & -1.147 & 0.314 & -1.258 & 0.175 & -1.589 & 0.312 & -0.258 & 0.581 & -0.785 & 0.324 & -1.456 & 0.312 \\
\hline$\overline{\min }$ & 2.325 & 0.185 & 3.258 & 0.189 & 2.365 & 0.542 & 4.189 & 0.189 & 1.852 & 0.178 & 3.741 & 0.291 & 2.018 & 0.214 & 2.921 & 0.412 \\
\hline \multicolumn{17}{|c|}{ Asia (1979-2004) } \\
\hline$t$ & -1.258 & 0.147 & -1.852 & 0.442 & -1.258 & 0.147 & -5.128 & 0.087 & -3.258 & 0.247 & -1.925 & 0.258 & -2.258 & 0.165 & -2.358 & 0.147 \\
\hline$\overline{L M}$ & 4.256 & 0.256 & 2.341 & 0.146 & 4.124 & 0.125 & 6.125 & 0.061 & 5.236 & 0.194 & 2.445 & 0.147 & 3.587 & 0.129 & 4.156 & 0.091 \\
\hline$\overline{\max }$ & -1.180 & 0.321 & -2.324 & 0.123 & -1.025 & 0.274 & -2.247 & 0.074 & -1.841 & 0.298 & -0.325 & 0.674 & -0.851 & 0.274 & -2.471 & 0.187 \\
\hline$\overline{\min }$ & 3.452 & 0.147 & 3.451 & 0.174 & 2.452 & 0.478 & 6.128 & 0.087 & 2.258 & 0.154 & 4.871 & 0.147 & 1.958 & 0.247 & 3.258 & 0.347 \\
\hline \multicolumn{17}{|c|}{ MENA (1979-2004) } \\
\hline$t$ & -3.258 & 0.108 & -2.658 & 0.214 & -1.457 & 0.139 & -6.124 & 0.071 & -2.258 & 0.584 & -2.258 & 0.158 & -2.698 & 0.184 & -3.258 & 0.128 \\
\hline$\overline{L M}$ & 6.158 & 0.148 & 4.125 & 0.054 & 4.325 & 0.114 & 6.471 & 0.065 & 5.625 & 0.174 & 2.897 & 0.143 & 5.214 & 0.136 & 5.124 & 0.102 \\
\hline $\max$ & -3.258 & 0.174 & -3.125 & 0.080 & -1.256 & 0.215 & -2.278 & 0.097 & -1.914 & 0.247 & -0.957 & 0.417 & -1.581 & 0.264 & -3.012 & 0.174 \\
\hline$\overline{\min }$ & 5.128 & 0.090 & 5.258 & 0.091 & 2.741 & 0.412 & 7.147 & 0.117 & 2.471 & 0.116 & 5.258 & 0.106 & 3.187 & 0.219 & 4.289 & 0.334 \\
\hline
\end{tabular}

Note: A rejection of the null hypothesis of non-stationarity for a given panel indicates that at least one country in the panel does not have a unit root and is stationary. The bootstrap p-values are, in each case, based on 5000 simulations. 


\subsubsection{Panel Cointegration Tests}

Having established the non-stationarity of the series, we then proceed to test for the existence of a long-run relationship between RER and its possible determinants as implied by equation (1). For this purpose, we implement the recent (second-generation) panel bootstrap cointegration test developed by Westerlund and Edgerton (2007). Compared with the (first-generation) panel cointegration tests proposed by Pedroni (1999, 2004), and generalised by Banerjee and Carrion-i-Silvestre (2006), this test has the advantage that the null hypothesis is that of the existence of a cointegration relation for all panel countries. Thus, if the null is not rejected, we can conclude that there is a long-run relationship for all panel countries, which is crucial to derive an estimate of the parameters of equation (1) and then evaluate the misalignment. However, this method has a serious limitation, namely the fact that a single country in the panel could cause the rejection of the null hypothesis, and it does not provide any information about which country (or countries) led to the rejection.

The new test developed by Westerlund and Edgerton (2007) is an extension of the Lagrange multiplier test of McCoskey and Kao (1998), and takes into account any correlations that might exist between the countries of the panel considered. In addition, using a "Sieve" bootstrap, it deals with the problem of the significant distortions resulting from the use of the asymptotic normal distribution, by generating critical values specific to the panel countries. It is therefore much more reliable than first-generation cointegration panel tests based on asymptotic distributions.

The results of this test are reported in Table 2. The bootstrap p-values indicate clearly the existence of a cointegration relationship between the real exchange rate (RER) and fundamentals as described by equation (1), for all emerging countries, as well for each of the three groups of countries, whilst the asymptotic p-values (not adjusted for sample size and possible dependence) lead to the opposite conclusion $^{14}$.

${ }^{14}$ As pointed out by a referee it is also worthwhile to use some panel cointegration tests with a null of no cointegration (in addition to the test of Westerlund and Edgerton, 2007, whose null hypothesis is joint cointegration for all countries), in order to see if these additional tests also reject that null, hence providing evidence that the cointegration results are robust. As mentioned by the same referee, "there are at least two reasons for using alternative tests. One is the well-known fact that classical hypothesis testing implies that the null hypothesis is accepted unless there is strong evidence to the contrary. The other reason is that the bootstrap test used here is new and its properties have been investigated only through a limited Monte Carlo exercise with one result that was "somewhat unexpected". In addition, the Monte Carlo exercise in Westerlund and Edgerton used two different values of $\mathrm{T}(50,100)$ which are bigger than the one used here $(\mathrm{T}=26)$ ". Therefore, in order to take into account possible cross-sectional dependence of panel units we have computed the bootstrap distribution of Pedroni's cointegration test statistic $(1999,2004)$, thereby generating data-specific critical values. As in Banerjee and Carrion-i-Silvestre (2006), we have of course not used the seven statistics proposed by Pedroni but only the parametric version of the statistics, i.e. the normalized bias and the pseudo t-ratio statistics, and in particular the ADF test statistics. These test statistics (available upon request) always reject the null hypothesis of no cointegration between RER and fundamentals, irrespective of whether the model includes a constant or a linear trend. These results are robust for the four groups of countries considered in our investigation (all emerging countries, Latin America, Asia and MENA) and thus provide additional support for cointegration. 
Table 2 - Cointegration tests of Westerlund and Edgerton, 2007, between the real exchange rate and its determinants (as specified in equation 1)

\begin{tabular}{lccc}
\hline $\begin{array}{l}\text { All countries considered } \\
\text { simultaneously (1979-2004) }\end{array}$ & LM-stat & $\begin{array}{c}\text { Asymptotic } \\
\text { p-value }\end{array}$ & $\begin{array}{c}\text { Bootstrap } \\
\text { p-value }\end{array}$ \\
\hline Model with constant & 1.758 & 0.000 & 0.154 \\
\hline Latin America (1979-2004)) & & & 0.133 \\
\hline Model with constant & 2.147 & 0.00 & \\
\hline Asia (1979-2004) & & & 0.341 \\
\hline Model with constant & 1.924 & 0.000 & \\
\hline MENA (1979-2004) & & & 0.461 \\
\hline Model with constant & 1.854 & 0.001 & \\
\hline
\end{tabular}

Note:

a- The bootstrap is based on 2000 simulations.

$\mathrm{b}$ - The null hypothesis is that of the existence of a long-run relationship between RER and fundamentals (see equation 1) for all countries of the panel considered.

For each of the four panels, the long-run coefficients estimated by the method of least squares dynamic (DOLS) developed by Kao and Chiang $(2000)^{15}$ are shown in Table 3.

Table 3: Cointegrating vectors (1979-2004) estimated by DOLS.

\begin{tabular}{ccccc}
\hline \hline & Emerging countries & Latin A. & Asia & MENA \\
\hline \multirow{2}{*}{$t t$} & 1.03 & 1.75 & 1.02 & 0.29 \\
& $(0.00)^{\mathrm{a}}$ & $(0.00)$ & $(0.00)$ & $(0.00)$ \\
dprod & 1.46 & 0.43 & -0.54 & 0.19 \\
& $(0.00)$ & $(0.00)$ & $(0.00)$ & $(0.16)$ \\
ps & 0.59 & 0.45 & 0.30 & 0.09 \\
& $(0.00)$ & $(0.00)$ & $(0.00)$ & $(0.00)$ \\
mon & 1.49 & 0.57 & -0.20 & 0.92 \\
& $(0.00)$ & $(0.00)$ & $(0.00)$ & $(0.00)$ \\
open & -1.09 & -1.36 & -0.38 & -1.10 \\
& $(0.00)$ & $(0.00)$ & $(0.00)$ & $(0.00)$ \\
if ${ }^{b}$ & -0.13 & -0.31 & -0.09 & -0.04 \\
& $(0.00)$ & $(0.00)$ & $(0.00)$ & $(0.00)$
\end{tabular}

\footnotetext{
${ }^{15}$ The reason why we have chosen to estimate the long-run coefficients by DOLS following Kao and Chiang (2000) and not by FMOLS (fully modified OLS) as proposed by Pedroni (2000) is the following observation of Kao and Chiang (2000, p 216), who notice that: « the OLS estimator has a non negligible bias in finite sample, FMOLS estimator does not improve over the OLS estimator. The FMOLS is complicated by dependence of the correction terms upon the preliminary estimator. More seriously, the failure of the non-parametric correction for the FM in panel could be severe. This indicates that DOLS estimator may be more promising than the OLS or FMOLS estimators in estimating cointegrated panel regressions".
} 


\begin{tabular}{ccccc} 
constante & 0.78 & 0.96 & 1.03 & 1.45 \\
& $(0.00)$ & $(0.00)$ & $(0.00)$ & $(0.00)$ \\
\hline $\mathrm{R}^{2}$ & 0.99 & 0.98 & 0.99 & 0.99 \\
$\mathrm{Nb}$. Obs. & 1009 & 515 & 256 & 232 \\
\hline \hline
\end{tabular}

Note:

a) The numbers in parentheses are p-values.

b) As a measure of international financial integration, we use IFI2 for all countries simultaneously and for Latin America, and NFA for Asia and the MENA.

The estimated coefficient for international financial integration for the three groups of countries confirm the theoretical predictions (see Obstfeld, 1984, Gavin, 1992). An increase of $1 \%$ in financial integration leads to a long-run RER depreciation of $0.13 \%$ and $0.31 \%$ for all countries simultaneously and for Latin America respectively. For Asia and the MENA region, an increase of $1 \%$ in financial integration (approximated by the NFA) leads to a RER depreciation of $0.09 \%$ and $0.04 \%$ respectively. In the long run, following the impact of financial integration, RER depreciation is required to correct the short-term current account deficit; therefore the Marshall-Lerner condition holds in the emerging countries. On the other hand, the medium run is characterised by the adjustment of net external assets to their desired level. The emerging countries seem to have a negative net asset position, and therefore record current account deficits and a RER appreciation. In the long run, the desirable NFA level is achieved: the increase in the stock of external debt leads to a RER depreciation, an improvement in the trade account and a trade surplus so that debt can be serviced.

As for financial integration, its coefficient is negative and statistically significant (at the $10 \%$ level), its effect being relatively more important in Latin America. This result gives empirical support to the models of Hooper and Morton (1982), Obstfeld (1984) and Gavin (1991). The econometric estimates also confirm that improved terms of trade lead to a RER appreciation in all countries simultaneously and in the three groups studied, which means that the wealth effect dominates the substitution effect. The difference in economic structures between the three groups of countries partly explains the different in RER responses following a shock to the terms of trade (an improvement of $1 \%$ in the terms of trade leads to an appreciation of $1.75 \%$ in Latin America, 1.02\% in Asia and $0.29 \%$ in the MENA region respectively).

The productivity differential also has a significant effect in all countries simultaneously and in the majority of countries (except the MENA group): its coefficient is positive (except for Asia), implying that economic growth is accompanied by a RER appreciation (which is consistent with the BalassaSamuelson effect). This effect is relatively important for Latin America, low in the MENA region and statistically significant, but negative for Asia (contrary to theory-based expectations). The (positive) 
effect of public spending on the real exchange rate is similar in the three groups: it leads to a RER appreciation in the long run consistently with theory (an increase of $1 \%$ causes an appreciation respectively of $0.59 \%$ in the panel with all countries, $0.45 \%$ in Latin America, $0.30 \%$ in Asia and $0.09 \%$ in the MENA region). As for the monetary variable, a positive shock to the money supply leads to a RER appreciation in Latin America and in the MENA region, and a depreciation in Asia. This can be explained by the adoption of expansionary policies in the latter. The negative coefficients for trade openness in all cases indicate that trade liberalisation was accompanied by RER depreciation. The effect is more important in Latin America and in the MENA region, and relatively minor in Asia. It should also be noted that, for Latin America and Asia, the external factors (terms of trade and trade openness for the former, and terms of trade for the latter) contribute most to the long-run dynamics of the RER. Domestic demand also plays a significant role in both regions, whilst in the MENA region monetary factors and trade openness are most important.

\subsubsection{Misalignment measurement}

To measure possible misalignments, first we compute the equilibrium real exchange rate by using the estimated coefficients (see Table 3) and the long-run values of the fundamentals, which are estimated using the Hodrick-Prescott (HP) filter, with the parameter $\lambda=100{ }^{16}$.

Misalignment is then calculated as follows:

Mis $=R E R-R E R^{p}=\mathrm{RER}-X^{P} \beta \mathrm{X}$

where $X^{P}$ is the permanent (trend) component of the fundamentals. If the gap is positive (negative), there is an over-(under)- evaluation of the national currency.

Figures 1 to 3 in the Appendix show the evolution over time of the RER misalignments in the three regions of the sample. There is clear evidence of either over- or under-valuation for all countries, confirming the recurrence and persistence of misalignments. Specifically, there is undervaluation in most countries in MENA, such as Jordan, Morocco, Syria and Tunisia, and overvaluation for most

\footnotetext{
${ }^{16}$ We are of course aware of the debate in the literature on the use of filters and that "filtering matters" particularly when using the HP, or the band pass filter. It has been shown (see, Guay and St-Amant, 2006) that the HP and BK filters do relatively well when applied to series that have a peak in their spectrum at low frequencies, but that they do poorly with series whose spectrum decreases sharply and monotonically at higher frequencies; i.e., series that have the typical spectral shape identified by Granger (1966). Consequently, the following simple strategy should be followed by applied researchers: estimate the spectral (or pseudo-spectral) density of the series of interest, so that the appropriateness of using the HP and BK filters to identify the cyclical component can be evaluated. The use of the HP and BK filters is very problematic when a series has the typical Granger shape.
} 
countries in Latin America and Asia. Such result can be explained by the adoption of more flexible exchange rate regimes in the MENA region in order to reduce misalignments and increase competitiveness, and it suggests that such flexibility is also required elsewhere. This is an interesting and important result, since it is based on more appropriate second-generation panel unit-root and cointegration tests which, to the best of our knowledge, have not been applied in the case of emerging countries in any other studies.

\section{Conclusions}

The aim of this study was to shed light on the determinants of the long-run equilibrium RER in emerging countries and to assess possible misalignments, focusing in particular on the long-run effects of international financial integration. Its contribution to the literature is twofold. First, we include international financial integration in the standard reduced-form model of the RER to test its impact on the long-run equilibrium and whether it leads to misalignments. Second, we carry out "secondgeneration" unit root and cointegration panel tests (taking into account possible cross-sectional dependence), which had not been previously done in this context. Using this approach, we are able to confirm the existence of a long-run relationship between the RER and various factors (including international financial integration) for all four panels considered (all countries, Latin America, Asia, the MENA), in contrast to what is concluded when relying on asymptotic critical values (which are not reliable for statistical inference here).

Our econometric analysis indicates that several factors affect the long-run RER, the signs of the estimated coefficients being consistent with theory. It is found that, in addition to other determinants normally considered in exchange rate models, international financial integration plays a key role, and has resulted in long-run RER depreciation and undervaluation. Also, persistent and recurrent misalignments are common in emerging economies, and take the form of an under-valuation in most MENA countries and an overvaluation in most Latin American and Asian countries. The latter two groups of countries would find it beneficial to adopt a more flexible exchange rate system (more compatible with the new financial architecture) in order to reduce RER misalignments. 


\section{References}

Aguirre, A. and Calderón, C, (2006), "Real Exchange Rate Misalignments and Economic Performance," Working Papers Central Bank of Chile 316, Central Bank of Chile.

Alberola, E. (2003), "Real Convergence, External Disequilibria and Equilibrium Exchange Rates In EU Acceding Countries”. Banco De España. Mimeo.

Alonso-Gamo, P., Fabrizio S., Kramarenko, V. and Wang, Q., (2002), "Lithuania: History and Future of the Currency Board Arrangement:," IMF Working Papers 02/127, International Monetary Fund.

Bai, J., Ng, S. (2004), A PANIC Attack on Unit Roots and Cointegration, Econometrica, 72 (4), 1271177.

Banerjee, A. and Carrion-i-Silvestre, J. (2006). "Cointegration in Panel Data with Breaks and Crosssection Dependence", European Central Bank, Working Paper 591, February.

Baldwin R. and Martin, P., (1999), Two Waves of Globalization, Superficial similarities, fundamental Differences, NBER Working paper, $\mathrm{n}^{\circ}$ 6904, January.

Bénassy Quéré.A, Duran Vigneron. P, Lahrèche Revil. A and Mignon. V., (2004), "Burden Sharing and Exchange Rate Misalignment within the group of twenty", CEPII, N 2004-13 September, pp 611

Bitans, M. and I. Tillers. (2003), "Estimates of Equilibrium Exchange Rate In Latvia. Latvijas Banka". Analysis of the Real Exchange Rate in Latvia: 1994- 2001. Bank Of Latvia. mimeo.

Blanchard O. and Quah, D. (1989), «The dynamic Effects of Agregate Demand and Supply Disturbances, » American Economic Review, Vol. 79, PP 655-73

Blecker, R.A., (2005), «Financial globalization, exchange rates, and international trade", From Financialization and the World Economy, edited by Gerald Epstein of the Political Economy Research Institute. Forthcoming from Edward Elgar, Spring 200, pp 1-10

Breton C. (2004), "Public debt and real exchange rate in a small open economy: a model with two sectors in a framework of New Open Economy", CEDERS.

Bruno, M. (1976) "The Two-Sector Model and the Real Exchange Rate." American. Economic Review 66, no. 4: 566-77.

Burgess, S. and Mawson, D., (2003) "Aggregate Growth and the Efficiency of Labour Reallocation," CEP Discussion Papers dp0580, Centre for Economic Performance, LSE.

Calvo, G Bordo, Michael D and Choudhri, Ehsan U, (1982) "Currency Substitution and the Demand for Money: Some Evidence for Canada," Journal of Money, Credit and Banking, Blackwell Publishing, vol. 14(1), pages 48-57, February. 
Choi, I. (2006), Combination Unit Root Tests for Cross-sectionally Correlated Panels, in Corbae, D., Durlauf, S. and Hansen, B. (eds), Econometric Theory and Practice: Frontiers of Analysis and Applied Research, Essays in Honor of Peter C. B. Phillips, Cambridge: Cambridge University Press.

Csajbok, A. (2003), “The Equilibrium Real Exchange Rate In Hungary: Results From Alternative Approaches". Paper Presented at the $2^{\text {nd }}$ Workshop On Macroecomic Policy Research, National Bank Of Hungary, October 2-3.

Darvas, Zs. (2001), "Exchange Rate Pass- Through and Real Exchange Rate in EU Candidate Countries", Economic Research Centre of the Deutsche Bundesbank Discussion Paper No. 10.

Dornbusch, Rudiger, and Stanley Fischer (1980) "Exchange Rates and the Current Account," American Economic Review 70, 960-71.

Drine, I. and Rault, C., (2005), "Déterminants de long terme des taux de change réels pour les pays en développement: une comparaison internationale", Revue d'Economie du Développement, vol 1, mai 2005.

Eatwell, J. (1996). "International Capital Liberalization: The Record." CEPA/New School for Social Research, working paper no. 1.

Edwards S., (1987), « Exchange rate misalignment in developing countries », Discussion Paper, NBER, n442, Mai.

Edwards, S., (1988), "Real and monetary determinants of real exchange rate behavior: Theory and evidence from developing countries," Journal of Development Economics, Elsevier, vol. 29(3), pp 311-341.

Edwards, S., (1989a), "Real Exchange Rate in the Developing Countries: Concepts and Measurement”, NBER, WP, N²950.

Edwards, S., (1993), "Exchange Rates, Inflation and Disinflation: Latin American Experiences," NBER Working Papers 4320, National Bureau of Economic Research.

Edwards S and Savastano M.A (1999), "Exchange rates in emerging economies: What Do We Know? What Do We Need to Know? NBER WP 7228, July.

Égert, B. Lahrèche- Révil, A. and Lommatzsch, K. (2004), “The Stock- Flow Approach To the Real Exchange Rate Of CEE Transition Economies", No - 15 November CEPII, Working Paper No 2004 15 Pp 4-28

Elbadawi, I. and B. Kamar. (2005). "The Great Debate on Exchange Rate Regimes: Why Should the MENA Region Care?" Paper Presented at the $12^{\text {th }}$ Economic Research Forum Conference, 17- 21 December, Cairo, Egypt. 
Elbadawi I., (1994), « Estimating long-run equilibrium real exchange rates », dans WilliamsonJ. (ed.), Estimating equilibrium exchange rates, Washington, D.C., Institute for International Economics, pp. 93-131.

Faruqee, H. (1995), "Long- Run Determinants Of the Real Exchange Rate: A Stock- Flow Perspective", IMF Staff Papers. 42 (1), 80- 107. Hinnosar, M., R. Juks,

Ferrari, J., (2000), « Economie Financière internationale », collection Amphi, Bréal 2000, pp 12-179.

Frankel, J.A. and Rose, A.K, (1996), "Currency crashes in emerging markets: An empirical treatment", Journal of International Economics 41(3-4), 351-366.

Gagnon J., (1993), « Exchange Rate Variability And the Level Of International Trade », Journal Of International Economics, $\mathrm{N}^{\circ}$ 34,p. 269- 287.10

Ganelli, Giovanni and Lane, P. R., (2002), "Dynamic General Equilibrium Analysis: The Open Economy Dimension," CEPR Discussion Papers 3540, C.E.P.R. Discussion Papers.

Gavin, M. (1992), "Monetary Policy, Exchange Rates and Investment in Keynesian Economy," Journal of International Money and Finance, vol 11, pp 145-161.

Hadri, K. (2000). "Testing for Stationarity in Heterogeneous Panel Data", Econometrics Journal, 3 (2), $148-161$.

Hooper, P., and J. Morton, (1982), "Fluctuations In the Dollar: A Model Of Nominal And Real Exchange Rate Determination,” Journal Of International Money And Finance 1, 39- 56.

Im, K. and Lee, J. (2001). "Panel LM Unit Root Test with Level Shifts", Discussion paper, Department of Economics, University of Central Florida.

Im, K. S., H. Pesaran, Y. Shin, and R. J. Smith, (2003), "Testing For Unit Root In Heterogeneous Panels" Journal Of Econometrics, Vol. 115, pp. 53- 74.

Kao, C., and M. H. Chiang, (2000), "On The Estimation And Inference Of a Cointegrated Regression In Panel Data," Advances In Econometrics, Vol. 15, pp. 179- 222.

Khan and Zahler (1983) "The Macroeconomic Effects of Changes in Barriers to Trade and Capital Flows: A Simulation Analysis", IMF Staff Papers, June 1983.

Krugman, Paul R. and Maurice Obstfeld (2003), «Économie internationale », 4e édition, De Boek éditeurs, 2003. ISBN: 2-8041-4359-7

Lane. Philip R and Milesi-Ferretti G.M., (2005), "Financial Globalization and Exchange Rates", International Monetary Fund, WP/05/3, January 2005, pp4-25

Lane. Philip R and Milesi-Ferretti G.M., (2006): "The External Wealth of Nations Mark II: Revised and Extended Estimates of Foreign Assets and Liabilities, 1970-2004", IMF Working Paper 06/69. 
Base de données disponible sur Internet :

http://www.imf.org/external/pubs/ft/wp/2006/data/wp0669.zip

Levin, A., Lin, C.-F. and Chu, C.-S. (2002). "Unit Root Tests in Panel Data: Asymptotic and Finite Sample Properties", Journal of Econometrics, 108 (1), 1-24.

Leybourne, S. (1995). "Testing for unit roots using forward and reverse Dickey-Fuller regressions", Oxford Bulletin of Economics and Statistics 57 (4), 559-571.

Lommatzsch, K. and S. Tober (2002), "What Is Behind the Real Appreciation Of the Accession Countries' Currencies? An Investigation Of the PPI- Based Real Exchange Rate". EU Enlargement." Budapest., November.

McCoskey, S., and Kao, C. (1998), “A Residual-Based Test of the Null of Cointegration in Panel Data," Econometric Reviews, 17, 57-84.

MacDonald, R. (1999), "Exchange Rate Behaviour: Are Fundamentals Important," The Economic Journal, Vol. 169, pp 673-691.

Maddala, G. S., and S. Wu, (1999), "A Comparative Study Of Unit Root Tests With Panel Data And a New Simple Test,” Oxford Bulletin Of Economics And Statistics, Vol. 12, pp. 167- 76.

Moon, H. and Perron, B. (2004), Testing for a Unit Root in Panels with Dynamic Factors, Journal of Econometrics, 122 (1), 8-126.

Morel and Perron (2003), "Relation entre le taux de change et les exportations nettes : test de la condition Marshall-Lerner pour le Canada ", L'Actualité économique, Volume 79, numéro 4, Décembre 2003, p. 481-502

Mussa M. and Goldstein, M., (1993), "The integration of world capital markets," Proceedings, Federal Reserve Bank of Kansas City, pages 245-330.

Neary P., (1988), « Determinants of the equilibrium real exchange rate », American Economic Review, 78(1), pp. 210-15.

Obstfeld, M. (2003). "Exchange Rates and Adjustment: Perspectives from the New Open Economy Macroeconomics," International Finance 0303004, EconWPA.

Obstfeld, M. and Rogoff, K.S., (1995), "Exchange Rate Dynamics Redux", Journal of Political Economy, 103(3), 624-660.

Obstfeld, M., (1984). "Balance-of-Payments Crises and Devaluation," Journal of Money, Credit and Banking, Blackwell Publishing, vol. 16(2), pages 208-17, May.

Obstfeld, M., (1998), “The Global Capital Market: Benefactor or Menace?” Journal of Economic Perspectives, Vol. 12 (Fall), pp. 9-30. 
Pedroni, P., (1999), "Critical Values for Co- Integration Tests In Heterogeneous Panels with Multiple Regressors," Oxford Bulletin Of Economics And Statistics, Vol. 61, pp. 653- 78.

Pedroni, P., (2004), "Panel cointegration. Asymptotic and finite sample properties of pooled time series tests with an application to the PPP hypothesis", Econometric Theory, Cambridge University Press, vol. 20(03), pages 597-625.

Pesaran, M. (2004). "General Diagnostic Tests for Cross Section Dependence in Panels". Cambridge Working Papers in Economics 435, and CESifo Working Paper Series 1229.

Pesaran, M.H. (2007), "A Simple Panel Unit Root Test in the Presence of Cross Section Dependence", Journal of Applied Econometrics, 22 (2), 265-312.

Prasad, E., Rogoff, K.S., Wei, S.-J. and Kose, M.A., (2003), "Effects of Financial Globalization on Developing Countries: Some Empirical Evidence," IMF Occasional Paper 220, August.

Rahn, J. (2003), "Bilateral Equilibrium Exchange Rates of the EU Accession Countries Against the Euro", BOFIT Discussion Paper No. 11.

Reinhart Carmen M. and Todd Smith, R., (2001) "Temporary Controls on Capital Inflows," NBER Working Papers 8422, National Bureau of Economic Research, Inc.

Smith, V., Leybourne, S. and Kim, T.-H. (2004). "More Powerful Panel Unit Root Tests with an Application to the Mean Reversion in Real Exchange Rates.' Journal of Applied Econometrics, 19 (2), 147-170.

Stein J. and Allen P. (1995), "Fundamental Determinants of Exchange Rates", Oxford Clarendon Press.

Stein, J. (1994), "The natural real exchange rate of the US dollar and determinants of capital flows", in Williamson, ed., Estimating Equilibrium Exchange Rates, Washington D.C: Institute for International Economics.

Stiglitz, J. E., (2002), “Globalization and Its Discontents”, New York: Norton.

Westerlund, J. and Edgerton, D. (2007). “A Panel Bootstrap Cointegration Test”, Economics Letters, forthcoming.

Williamson, J. (1985), “The Exchange Rate System”, Policy Analyses in International Economics, 5, Washington D.C: Institute for International Economics.

Williamson, J. (1994), "Estimates of FEERs", in Williamson ed., Estimating Equilibrium Exchange Rates, Washington D.C: Institute for International Economics.

Statistic Database: CD-ROM: Chelem (2005), IFS (2006), WDI (2006). 


\section{Appendix}

Fig. 1: Evolution of RER Misalignment in MENA (1979-2004)

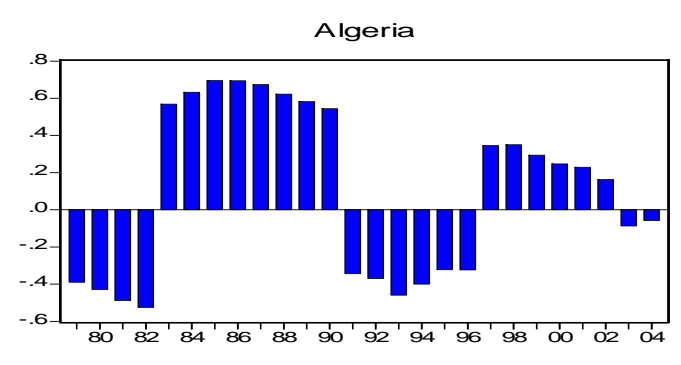

Israel

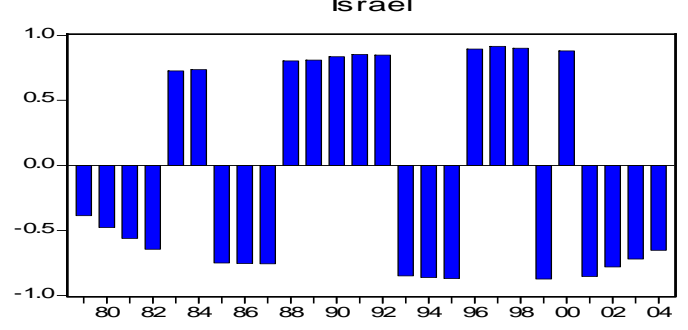

Syrian

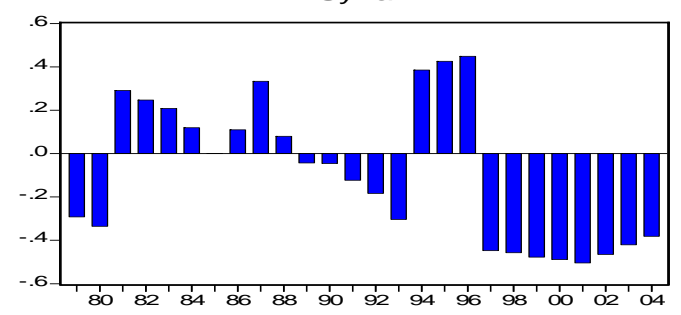

Egypt

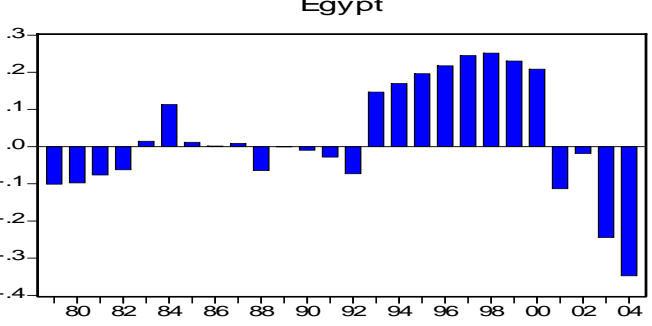

Jordan

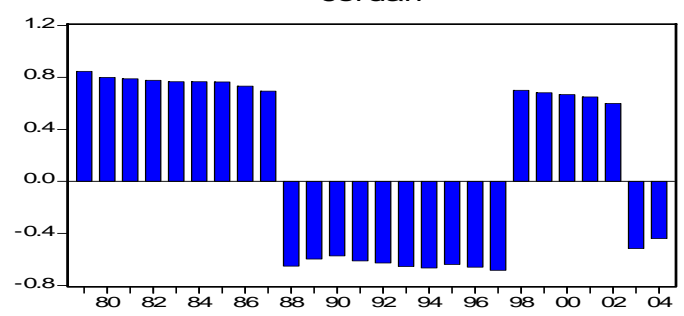

Tunisia

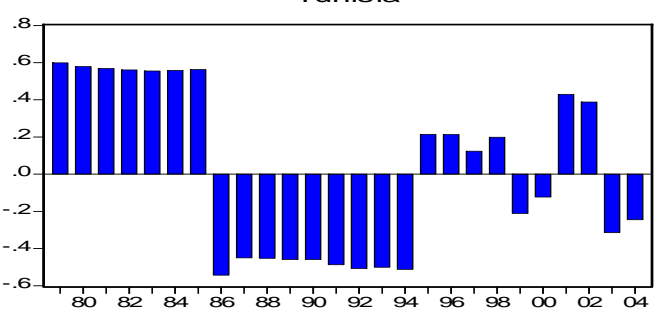

Iran

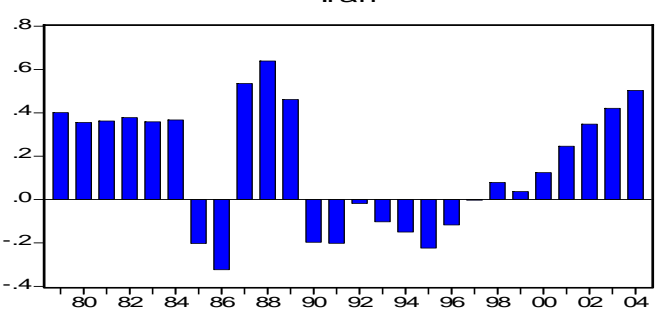

Morocco

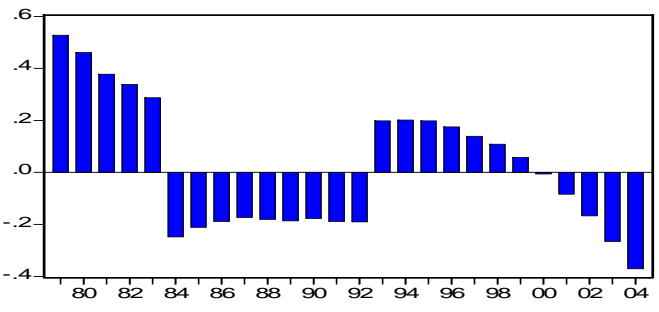

Turkey

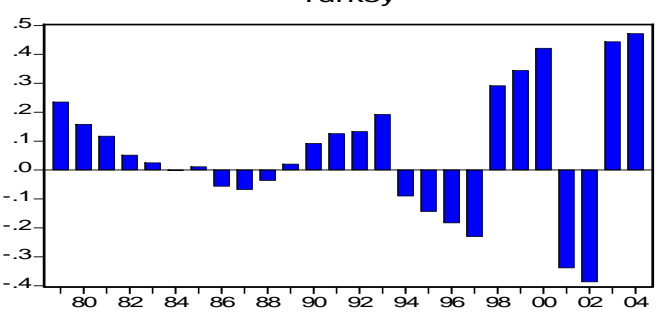

Sources: our calculations using data from the IMF's International Financial Statistics (IFS, 2006), and World Development Indicators (WDI, 2006) 
Fig. 2: Evolution of RER misalignment in Asia (1979-2004)
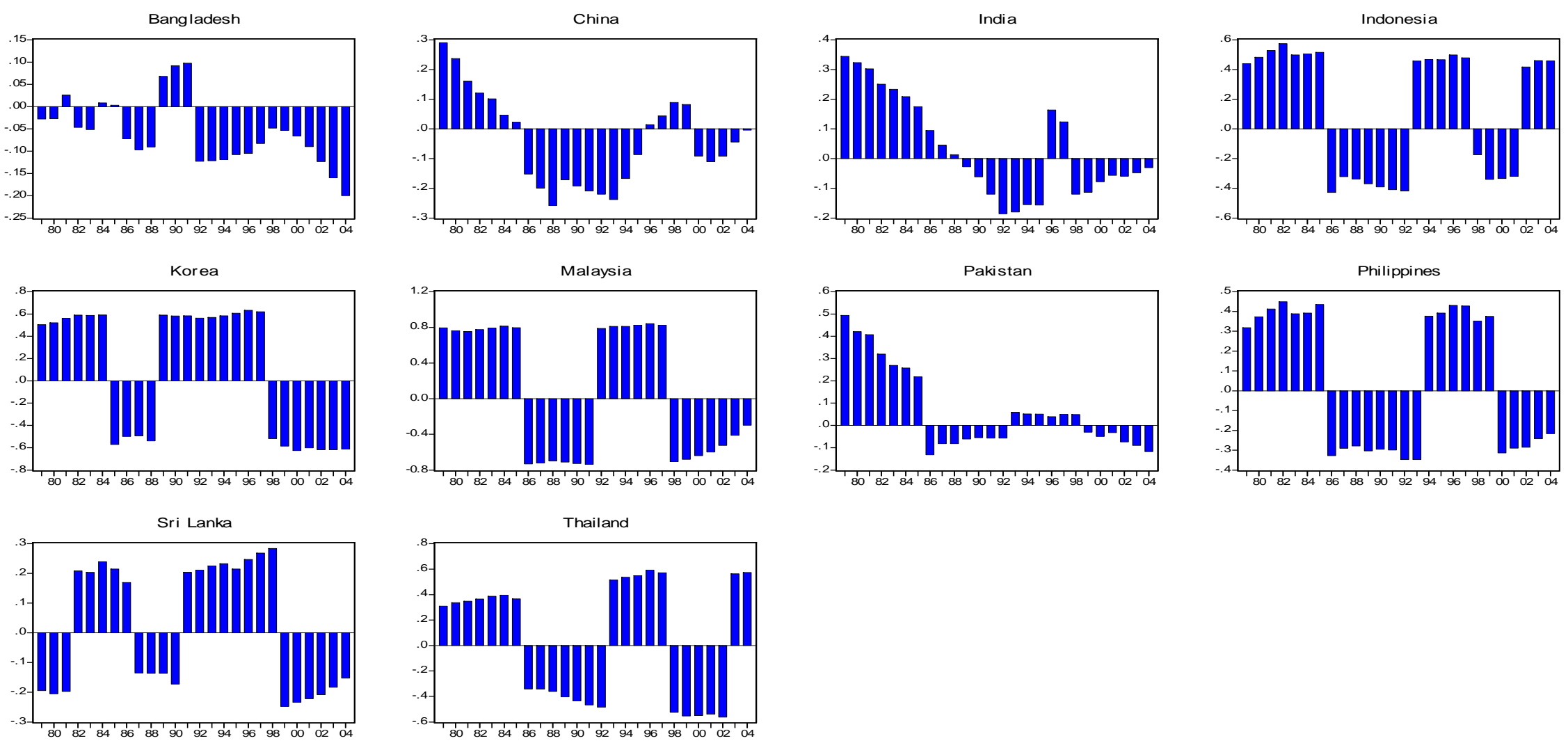

Sources: our calculations using data from the IMF's International Financial Statistics (IFS, 2006), and World Development Indicators (WDI, 2006) 
Fig. 3 Evolution of RER Misalignment in Latin America (1979-2004)
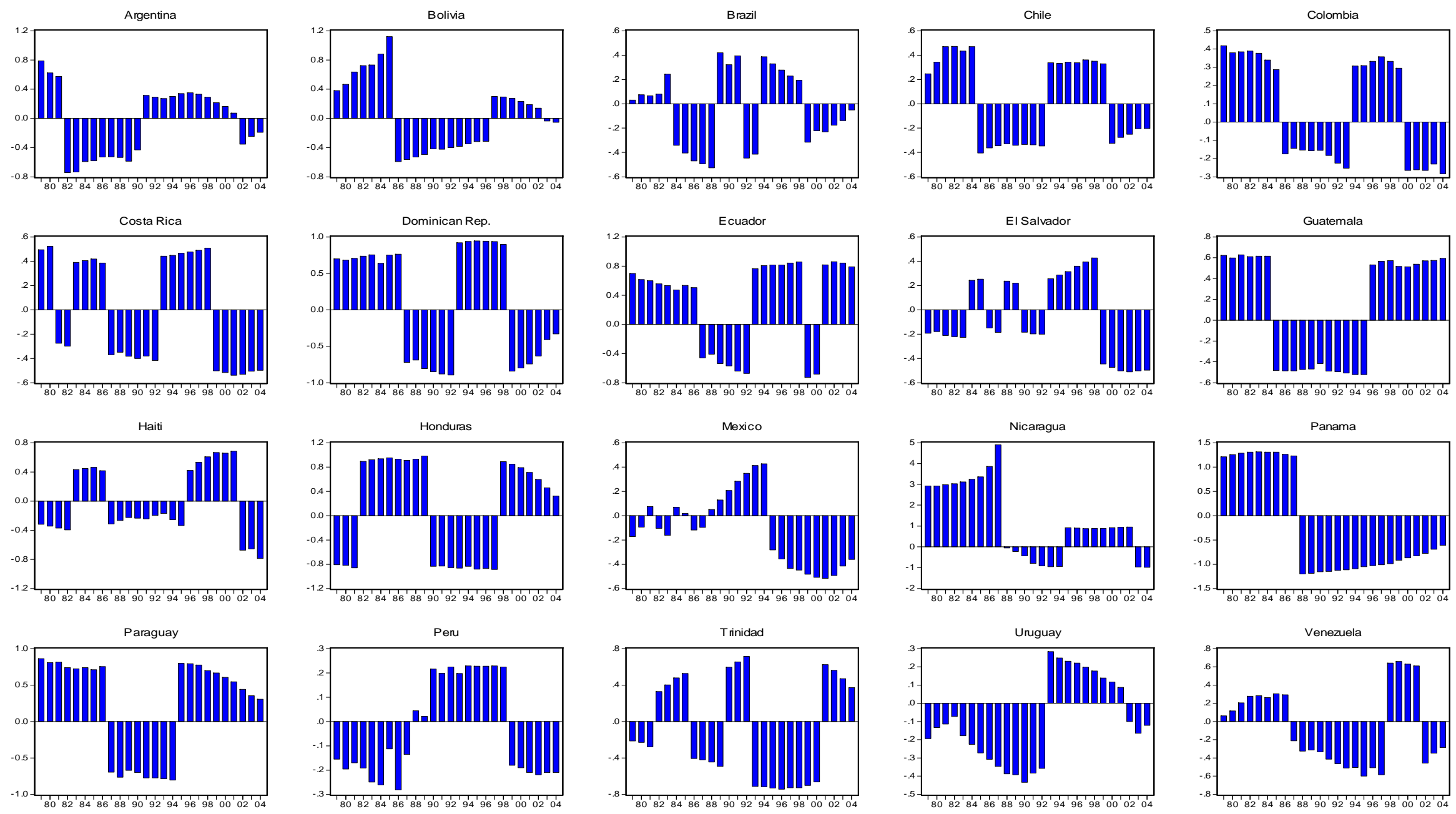

Sources: our calculations using data from the IMF's International Financial Statistics (IFS, 2006), and World Development Indicators (WDI, 2006) 


\section{DAVIDSON INSTITUTE WORKING PAPER SERIES - Most Recent Papers}

The entire Working Paper Series may be downloaded free of charge at: www.wdi.umich.edu

CURRENT AS OF $10 / 7 / 09$

\begin{tabular}{|c|c|c|}
\hline Publication & Authors & Date \\
\hline $\begin{array}{l}\text { No. 970: International Financial Integration And Real Exchange Rate } \\
\text { Long-Run Dynamics In Emerging Countries: Some Panel Evidence }\end{array}$ & $\begin{array}{l}\text { Guglielmo Maria CAPORALE, } \\
\text { Thouraya HADJ AMOR } \\
\text { and Christophe RAULT }\end{array}$ & Sept 2009 \\
\hline $\begin{array}{l}\text { No. 969: Once Bitten, Twice Shy: Experiences Of A Banking Crisis } \\
\text { And Expectations Of Future Crises }\end{array}$ & Shannon Mudd \& Neven Valev & Sept 2009 \\
\hline $\begin{array}{l}\text { No. 968: Monetary policy rules and inflation process in open emerging } \\
\text { economies: evidence for } 12 \text { new EU members }\end{array}$ & Bořek Vašíček & Sept 2009 \\
\hline $\begin{array}{l}\text { No. 967: Extending Likages Between Organizational Analysis And Social } \\
\text { Structure: A Case Study Of The Celebrity-Construction Of A Chinese } \\
\text { Marketplace }\end{array}$ & Mark Jacobs & Aug 2009 \\
\hline $\begin{array}{l}\text { No. 966: Chinese state's economic cooperation related investment: An } \\
\text { investigation of its direction and some implications for outward } \\
\text { investment }\end{array}$ & $\begin{array}{l}\text { Sumon Bhaumik and } \\
\text { Catherine Yap Co }\end{array}$ & Aug 2009 \\
\hline $\begin{array}{l}\text { No. 965: Capital inflows, household debt and the boom-bust cycle in } \\
\text { Estonia }\end{array}$ & $\begin{array}{l}\text { Zuzana Brixiova, Laura Vartia } \\
\text { and Andreas Worgotter }\end{array}$ & July 2009 \\
\hline No. 964: Labour Market Felxibility in Estonia: What More Can be Done? & Zuzana Brixiova & July 2009 \\
\hline $\begin{array}{l}\text { No. 963: Market Globalization by Firms from Emerging Markets \& Small } \\
\text { Countries: An Application of the Neoclassical Trade Model }\end{array}$ & Tamir Agmon & July 2009 \\
\hline $\begin{array}{l}\text { No. 962: Central Bank Communication and Exchange Rate Volatility: A } \\
\text { GARCH Analysis }\end{array}$ & $\begin{array}{l}\text { Roman Horvath and Radovan } \\
\text { Fiser }\end{array}$ & July 2009 \\
\hline $\begin{array}{l}\text { No. 961: On the influence of oil prices on stock markets: } \\
\text { Evidence from panel analysis in GCC countries. }\end{array}$ & $\begin{array}{l}\text { Christophe Rault and Mohamed } \\
\text { El Hedi Arouri }\end{array}$ & June 2009 \\
\hline $\begin{array}{l}\text { No. 960: Oil Prices \& Stock Markets: What Drives What in the Gulf } \\
\text { Corporation Council Countries? }\end{array}$ & $\begin{array}{l}\text { Christophe Rault and Mohamed } \\
\text { El Hedi Arouri }\end{array}$ & June 2009 \\
\hline $\begin{array}{l}\text { No. 959: Trade Specialisation And Economic Convergence: } \\
\text { Evidence From Two Eastern European Countries }\end{array}$ & $\begin{array}{l}\text { Christophe Rault, Guglielmo } \\
\text { Caporale, Robert Sova \& } \\
\text { Anamaria Sova }\end{array}$ & June 2009 \\
\hline $\begin{array}{l}\text { No. 958: Inflation differentials in the Euro area and their determinants } \\
\text { - an empirical view }\end{array}$ & $\begin{array}{c}\text { Juan Ignacio Aldasoro \& Václav } \\
\text { Žd'árek } \\
\end{array}$ & April 2009 \\
\hline No. 957: Infrastructure and growth: Empirical evidence & $\begin{array}{c}\text { Balazs Egert, Tomasz } \\
\text { Kozluk and Douglas Sutherland }\end{array}$ & April 2009 \\
\hline $\begin{array}{l}\text { No. 956: Infrastructure investment in network industries: The role of } \\
\text { incentive regulation and regulatory independence }\end{array}$ & Balazs Egert & April 2009 \\
\hline $\begin{array}{l}\text { No. 955: The impact of monetary and commodity fundamentals, macro } \\
\text { news and central bank communication on the exchange rate: } \\
\text { Evidence from South Africa }\end{array}$ & Balazs Egert & April 2009 \\
\hline $\begin{array}{l}\text { No. 954: "Family" ownership, tunneling and earnings management: } \\
\text { A review of the literature }\end{array}$ & $\begin{array}{l}\text { Sumon Bhaumik and Andros } \\
\text { Gregoriou }\end{array}$ & $\begin{array}{l}\text { March } \\
2009\end{array}$ \\
\hline $\begin{array}{l}\text { No. 953: Impact of Foreign Direct Investments on Industrial Productivity: } \\
\text { A Subnational Study of India }\end{array}$ & Krishna C. Vadlamannati & $\begin{array}{l}\text { March } \\
2009\end{array}$ \\
\hline $\begin{array}{l}\text { No. 952: Determinants of Exchange Rate Practices in the MENA } \\
\text { Countries: Some Further Empirical Results }\end{array}$ & Sfia, M. Daly and Mouley Sami & Jan 2009 \\
\hline No. 951: An Analytic Approach To Selecting A Nonprofit & $\begin{array}{l}\text { Andrés Ramírez and } \\
\text { Hakan Saraoglu }\end{array}$ & Jan 2009 \\
\hline $\begin{array}{l}\text { No. 950: Anthropometry of Love } \\
\text { Height and Gender Asymmetries in Interethnic Marriages }\end{array}$ & Michèle Belot and Jan Fidrmuc & Jan 2009 \\
\hline No. 949: IS THE COST OF LIVING IN RUSSIA REALLY THAT LOW? & Konstantin Gluschenko & Dec 2008 \\
\hline $\begin{array}{l}\text { No. 948: Banking Market Liberalization and Bank Performance: the Role } \\
\text { of Entry Modes }\end{array}$ & Ngoc-Anh Vo Thi & Jan 2009 \\
\hline
\end{tabular}

